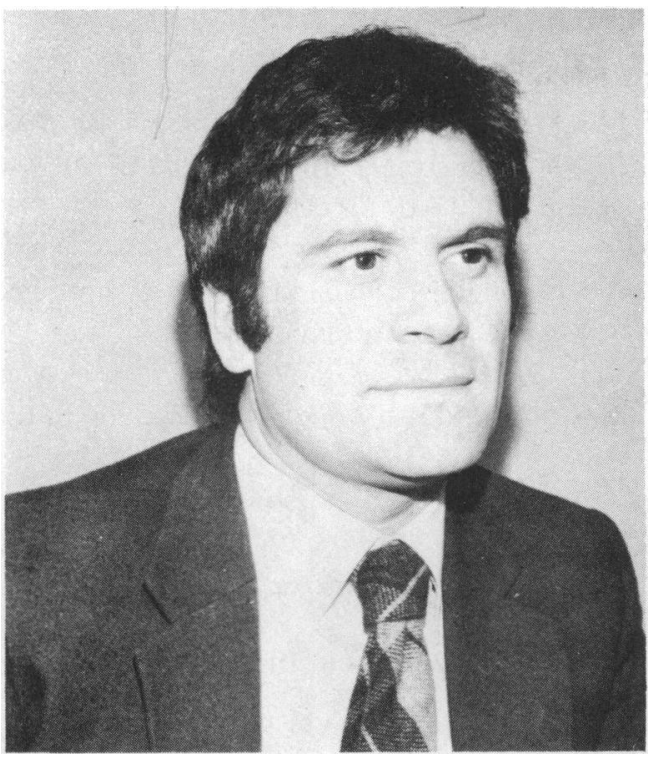

\section{A DOUBLE-BLIND TRIAL OF IBUPROFEN AND ASPIRIN IN THE TREATMENT OF SOFT-TISSUE INJURIES SUSTAINED IN PROFESSIONAL FOOTBALL}

\author{
D. S. MUCKLE, FRCS
}

Department of Orthopaedic Surgery, General Hospital, Middlesbrough
Of ten thousand patients seen in the Orthopaedic Department of the Middlesbrough General Hospital, about one thousand are sportsmen, and overall the majority suffer an injury or disease of the collagen tissues with or without bone involvement. An important factor in soft-tissue lesions is the bio-feedback neurological mechanisms controlling joint movement, bone and muscle growth, and calcification of bone.

The investigation of an injury may be very difficult, and a straight $X$-ray will only show up lesions involving $65 \%$ of bone destruction or more. They usually fail to display soft tissue trauma, and even a $10 \mathrm{~cm}$ gap in an Achilles tendon may not be seen. Aspiration of joints with analysis of the aspirate may be helpful immediately after injury, but not if several days have elapsed.

For the study reported, professional football players were used. Their performance ratings in speed, turning ability, jump height and other parameters were all recorded during training, and available to the investigator, who served as doctor to the club and saw players within a few minutes of injury. From a practical point of view, it was necessary to be able to decide as soon as possible when the player could commence training again, and when he could next play. In most clubs, if a player cannot resume full training on Thursday, he will not be selected to play on Saturday. Early and effective treatment is therefore essential, from the player's financial aspect apart from all others.

From information published, it would appear that non-steroidal anti-inflammatory agents which block prostaglandin formation, or the presence of their breakdown products, endoperoxides, would be well worth investigating for acute injury. ( $V$ ane et al 1971: Adams, S., Crunkhorn and Willis (1971) had already shown the prostaglandin inhibitory effect of soluble aspirin, and Adams et al (1970) working with the development of non-steroidal anti-inflammatory drugs, showed the rapid effect of Ibuprofen in acute injury in animal experiments. The results encouraged us to compare these two drugs on recently injured football players.

\section{METHOD}

Ibuprofen was administered in moderate doses, 1,200 $\mathrm{mg}$ in divided doses between the afternoon of injury and bed time the same day. The aspirin dosage was $3,600 \mathrm{mg}$ in the same period. On the following days the same dosage of drugs was given, spread evenly throughout the day. No other therapy was given apart from active and passive movements and resisted exercise.

\section{RESULTS}

Subjective pain scores were analysed, and the results of aspirin therapy compared with lbuprofen. For the first three days after injury and on treatment, there was an appreciably better response to Ibuprofen, with regards to pain relief. On average, the Ibuprofen group were able to play after 6.2 days, and the aspirin group after $\mathbf{9 . 5}$ days. After the third day, there was little difference in subjective pain, but a large difference in resumption of playing fitness.

After the initial trial reported, and as a result of studies on toxicity, it was decided to increase the dose of Ibuprofen to $2,400 \mathrm{mg}$ daily for the first five days, and higher doses have sometimes been needed. 

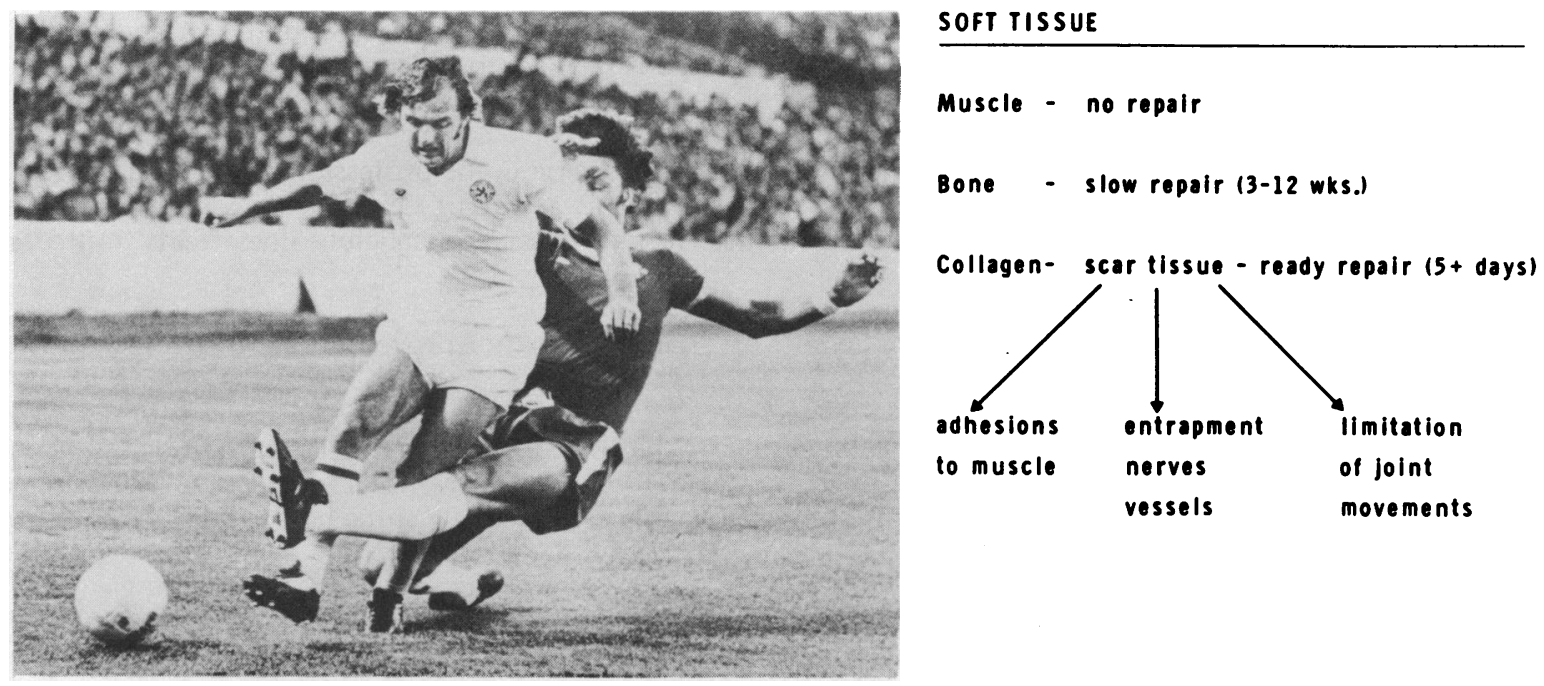

Analysis of number of days

(a) to commencement of training

and (b) to match fitness

\begin{tabular}{|c|c|c|c|c|c|c|c|c|c|c|}
\hline Diagnosis & Drug & $\begin{array}{l}\text { No. of } \\
\text { pationts }\end{array}$ & Mean & $\mathbf{t}$ & df & Probability & Mean & $t$ & df & Probability \\
\hline Sprain & $\begin{array}{l}\text { Aspirin } \\
\text { lbuprofen }\end{array}$ & $\begin{array}{r}5 \\
12\end{array}$ & $\begin{array}{l}6.60 \pm 1.29 \\
3.25 \pm 0.55\end{array}$ & 2.72 & 15 & $0.02>p>0.01$ & $\begin{array}{l}9.2 \pm 1.39 \\
5.33 \pm 1.12\end{array}$ & 2.03 & 15 & $0.1>p>0.05$ \\
\hline Trauma & $\begin{array}{l}\text { Aspirin } \\
\text { Ibuprofen }\end{array}$ & $\begin{array}{l}25 \\
18\end{array}$ & $\begin{array}{l}6.64 \pm 0.80 \\
4.17 \pm 0.58\end{array}$ & 2.51 & 41 & $0.02>p>0.01$ & $\begin{array}{l}9.60 \pm 1.04 \\
6.78 \pm 1.08\end{array}$ & 1.99 & 41 & $0.1>p>0.05$ \\
\hline All patients & $\begin{array}{l}\text { Aspirin } \\
\text { lbuprofen }\end{array}$ & $\begin{array}{l}30 \\
30\end{array}$ & $\begin{array}{l}6.63 \pm 0.69 \\
3.80 \pm 0.42\end{array}$ & 3.81 & 58 & $p<0.001$ & $\begin{array}{l}9.53 \pm 0.89 \\
6.20 \pm 0.79\end{array}$ & 3.08 & 58 & $0.01>p>0.001$ \\
\hline
\end{tabular}

\section{DISCUSSION}

It should be possible to modify the immediate reaction of soft tissues to injury by anti-inflammatory drugs, whether the reaction is due to prostaglandin formation or to the previously held histamine - bradykinin serotinin theories.
In general practice, with those soft-tissue injuries seen within a few hours, adequate doses of an antiinflammatory non-steroidal drug are likely to give rapid analgesia and an early return to work or sport. With chronic injuries, they are unlikely to have any effect other than the analgesic one.

\section{DISCUSSION}

\section{ANTI-INFLAMMATORY DRUGS IN SOFT-TISSUE SPORTS INJURIES}

J. G. P. WILLIAMS raised the possibility that aspirin might have delayed healing, as no "no-treatment" control group was used for comparison.

D. S. MUCKLE mentioned a small-scale trial in which $4 \mathrm{G}$. of aspirin daily was used, and gave better results than the lower dose. The beneficial effects of both drugs, aspirin and Ibuprofen, were largely dose-related, but lbuprofen was shown to have fewer side-effects than other anti-inflammatory agents, and could be used in high doses. 